\title{
Review: Danish Dragonflies
}

\author{
Nielsen, O.F. 1998: De danske guldsmede Danmarks Dyreliv, Bind 8 (The Dragonflies of Denmark. \\ Animal Life of Denmark, vol. 8)
}

Apollo Books has again delighted the entomologists in Denmark, this time by publishing a marvellous book about Danish dragonflies! On the first few pages, all the persons who participated in compiling the book and the contents are mentioned. In the preface, the author, Ole Fogh Nielsen, tells his history as a dragonfly expert. He started in the normal way by collecting butterflies. Quite soon he added photography to his hobbies, and about ten years ago he began toconcentrate upon dragonflies and their larvae. One of his major problems in this new field was the lack of more recent literature. He therefore decided to write a book himself.

In the Introduction, the author guides us to the fascinating world of dragonflies demonstrating especially their unbelievable flight ability. Discussing the larvae, he points out their meaning as both prey and predators in all kind of waters. He also draws our attention to the significance of these insects as biological indicators, which date back as long as 325 million years. He gives a short review about the research history in Denmark. One possible reason why these big and beautiful insects have not yet attracted many people to work on them may be the fact that imagos lose their colors quite soon after killing. Another reason is probably the lack of modern books. In Europe however, two books have been published which have made it possible to identify even Danish dragonfly specimens.

The next chapter "Life cycle and Systematics" starts from the ancient history and tells that, even in the "Coal Era" 325 million years ago, there were insects similar to dragonflies, one of the most impressing being Meganeura monyi with a wing span of $70 \mathrm{~cm}$ ! Nowadays, about 600 fossil species are known. Some fossil dragonflies have even been found in Denmark, dating back 54 million years. Odonata is one of the 30 insect orders which are quite distant from the others, with the exception of Ephemeroptera, to which they are most closely related. Altogether 5300 species are known, which is a surprisingly low number. Out of these, 114 species are found in Europe and 53 in Denmark. At the end of the chapter the suborders and the structure of the Latin nomenclature are presented.

The chapter titled "Life cycle" is long and thorough. It has been divided into several subheadings, such as "Imagos", "Ecdysis", "Maturing" etc. There are many interesting details about the ecology of dragonflies. Aeshna juncea is said to have a life cycle of 5-6 years in northern Scandinavia, while the Sympecma species, which overwinter as imagos, can develop from an egg to adult within three months. Dragonfly adults are rather long-lived with Anax imperator occurring for up to 60 days. Some others, such as Enallagma cyathigerum, however, only live for 12 days. The adult morphology is described in detail. It may take up to two days for the body to harden sufficiently for the individual to start normal life. Adult males have territories which they defend against other males and where they try to catch their prey or a find a female. The flight ability of dragonflies is exceptional. Some species can fly even at $100 \mathrm{~km} /$ hour. Most fascinating is, however, their ability to make difficult meneuvers in the air - they can move their fore- and hindwings unsynchronously. Migrations are well known for many insects, especially butterflies. Dragonflies also migrate over shorter or longer distances, and even mass migrations are known for some species.

Dragonflies are predators and catch almost solely flying prey items. Aeshna cyanea has been reported to have eaten Pieris brassicae and Gonepteryx rhamni! They find their mates visually. Dragonflies do not use smell or voice signals at all, like many other insects do. Copulation is done by most species without any rituals as soon as the male has localised a female. The curious copulation is described in detail. The description of egg laying is also full of small interesting details. Some species lay their eggs in plants in water, some just drop them into water and some even on dry ground in the hope that there would be enough water in the following spring for larvae to develop.

The chapter on "Dragonfly larva" tells us about the hatching of prolarvae which only lasts for some minutes and which has no other aim than to get the prolarva into water and to hatchit into a proper larva. The development and structure of the larva is described. Especially the modified labrum, the mask, is worth mentioning. The larvae use it to catch prey, which they normally do by the "sit and wait" method. A short chapter is also given about the common ecology of Odonata. It is partly continued under the heading "Friends and enemies", where the author fells about the different predators that use dragonfly adults or larvae as prey. The author here invites attention to the fact that large-scale pollution and massive soil construction have destroyed the habitats of many dragonflies. On the other hand, rather modest efforts would be enough to restore these water watersheds to such a condition that the original fauna could recolonise them.

The long chapter titled "To Study and Photograph Dragonflies" includes many good hints for a beginner and even for a person who has been dealing with these insects for years. One of the most striking recommendations, but surely a very useful one, was this: take many photos, choose the best immediately and throw the rest away! There are also some words about how to collect, and preserve and identify larvae. Quite 
exceptional is the possibility to collect empty excuviae - they can be identified as easily as the larvae, which helps one to avoid killing them. Before the author starts to present the Danish species one by one, there is a short presentation about the status and distribution of species in Denmark. The major part of the book is composed of species descriptions. Every species is discusses very thoroughly, including the appearance, habitats, adfaerd, life cycle, flight time and distribution in Denmark and southern Scnadinavia. This part is full of about these species. But especially, it is full of splendid colour photos about the species and their habitats. These really help one to get an idea of how each species looks and what kind of surroundings they live in.

At the end of the book, there is a checklist of Danish Odonata and good keys to both adults and larvae. These make the book really versatile and useful for the reader and ensure that the pages will wear out in the hands of entomologists. The Danish language was a bit hard, but with the aid of school
Swedish and a dictionary, even a northern guy like myself could get the basic message of the book. I can only congratulate the author and the publisher about this splendid book, which can be recommended to all entomologists and especially to those working with dragonflies or aquatic insects in general.

Ole Fogh Nielsen De Danske Guldsmede Danmarks Dyreliv, Bind 8 (The Dragonflies of Denmark, Animal Life of Denmark, vol. 8). 1998, 279 pages. 233 colour illustrations. Distribution maps of all species. 258 line drawings. Systematic treatment of all species known from Denmark. Identification keys. Text in Danish. Hardback with dust cover. ISBN 87-88757-21-8. Published by Apollo Books, Kirkeby Sand 19, DK-5771 Stenstrup, Denmark and available at a price of Danish Kroner 300,00 excl. Postage.

Juhani Itämies 